\title{
The Second Wave: The Collapse of Communism and 9/11
}

The end of the Cold War entailed liberal democracy becoming an almost uncontested new master framework in the West. As I discussed in the Introduction to this book, many scholars wrote that politics would from then on predominantly be conducted within the parameters of representative democratic governance in an open and free market economy. Francois Fukuyama (1992), for instance, wrote that the opening of the Iron Curtain marked the 'universalization of Western liberal democracy as the final form of human government.'

However, history has proved this not to be entirely the case. Only a year later Samuel Huntington contested this prediction of a rosy future when publishing his article and later book, Clash of Civilizations. In his famous writings Huntington $(1993,1996)$ instead predicted that with the collapse of communism Islam would emerge as the main ideological adversary of the West.

In this chapter I analyse the second wave of nativist populism in the post-war era, rising in 1989 in the wake of the collapse of communism and fall of the Berlin Wall. Some of the populist parties finding success in the second and third waves were previously established, a few even initially as mainstream parties, only later turning populist, as was the case in Austria and Switzerland. Aikin to the Oil Crisis of 1972, that had come as a surprise to most people, the political upheaval in 1989 with the collapse of the Berlin Wall also came unannounced. The political class-academics and politicians alike-failed to predict the downfall of the Eastern bloc. 
As will become evident in this chapter, the nature of the nationalism introduced in the second wave was somewhat different to that of the previously discussed agrarian populism or the anti-tax neo-liberal populism in the early 1970s. Rather than primarily referring to the social-economic situation of the ordinary people, the emphasis moved over to a sociocultural notion of our people.

It can be argued that the nativist populism in the second wave was gradually replacing or at least augmenting the anti-tax and neo-liberal populism of the first wave. Although xenophobia and ethno-nationalism was surely a significant part of the populist message from the outset-as was established in the previous chapter when for example discussing the French National Front, Nouvelle Droite and the Identitarians-that sort of rhetoric rose much more clearly to the forefront in the second wave. A culturally based ethno-pluralism was now growing beyond that of the primarily economic aspects of the first wave.

\section{Ever Closer Union}

Significantly for the backlash against supranational solutions which occurred later, and which I will analyse further in the following chapter, European leaders at the time responded to the dramatic events around the collapse of the Berlin Wall by gearing up their economic co-operation within the European Community (EC), into becoming a fully-fledged economic and political European Union. The Maastricht Treaty of 1992 tightened and deepened the integration process and set in place mechanisms for anticipated accession of most of the newly liberated states on the Eastern side of the fallen Iron Curtain. The new arrivals seeking a 'return to Europe', as it was branded, would have to meet three main overall criteria. One was stability of institutions guaranteeing democracy, the rule of law, human rights and respect for and protection of minorities. Another was the existence of a functioning market economy. A third criteria was on the administrative capacity of absorbing European laws and regulations.

Leading up to the coming Eastern enlargement, the EU signed partnership agreements with each of the candidate countries. Trade relations were fast increasing and after only few years of transition in the wake of the EU accession in 2004 and 2007, citizens of the former Eastern bloc gained the right to work across the region. For a continent that for half century had been separated into two parts, this was a dramatic and initially highly celebrated change. 
Another signpost of renewed unison was built when most EU members states united in a single currency, the Euro. Many believed that the Euro would bring a fresh feeling of shared belonging. However-as I will illustrate in the following chapter-when the Euro Crisis hit in 2008/9, many blamed the European apparatus.

As I mentioned in the Introduction to this book, many people were in this period of internationalized liberal democracy predicting the diminishing significance of the nation-state. Philosopher Jürgen Habermas (1998), for instance, went so far as predicting that Europe was moving in direction of a 'post-national constellation'. However, even though the end of the Cold War surely brought renewed unity in Europe, it also led to conflicts. Most notorious was the outbreak of the war on the Balkan peninsula which lasted between 1991 and 2001 and costed 140,000 people their lives.

\section{RE-DRAWN Dividing Lines}

The collapse of the communist Eastern bloc did not only introduce capitalism and democracy to the newly liberated states, it also reinvigorated long suppressed national sentiments in these lands, often channelled through ethno-nationalist parties that were being established across the region. The Yugoslav War brought nationalism back with a vengeance, resembling only that of the interwar period. It proved to be Europe's deadliest war since World War II. In Serbia, Slobodan Milosevic rose on a renewed nationalist rhetoric which promoted creating a 'Greater Serbia' by annexing swaths of Croatia and Bosnia.

The Socialist Federal Republic of Yugoslavia, established after World War II, tied together the predominantly Christian nations of Serbia, Slovenia, Croatia and Macedonia and the mostly Muslim dominated Bosnia and Herzegovina. Its authoritarian leader, Josip Broz Tito, was successful in suppressing nationalism and keeping the coherence of the state. In the wake of his death in 1980, secessionist forces slowly started to re-emerge. With the collapse of the communist block the federal state disintegrated along national lines. In the conflict, both Serbian and Croatian forces turned to ethnic cleansing, with the aim of forcing unwanted ethnic groups out of their lands. The conflict marked the return of separatism in Europe and the renewed rise of authoritarian populism.

Anti-Muslim sentiments surely played a part in the horrendous actions of Serbian forces in Bosnia Herzegovina. It is generally accepted that their 
actions escalated into the genocide of Bosniaks. The Yugoslavian War furthermore led to a renewed avalanche of refugees fleeing over to Western Europe, mainly to Germany and also to Scandinavia. Once again, millions of people were on the move, many of them undocumented.

In most countries in Eastern Europe, the post-Cold-War era saw a rise of neo-liberal policies. This was indeed a period of Thatcherite privatization politics on steroids. In most instances the communist welfare system was completely dismantled. This led to an immense drop in industrial output, mass unemployment and wide-scale economic hardship for most people, but mammoth wealth accumulation for the few who were in positions of power. In turn, this evolution led to fast progressing inequality, even far beyond Western levels. At the same time, East Europeans were flocking to the West.

Most of the countries in the East were eager to join the EU. In a way it was like rejoining Europe. This led to increased tension in the receiving countries. Many responded with enhanced restrictions and assimilation requirements were hardened. While the European Union, as such, was promoting co-operation with the former communist East, many of its members states were still looking for ways to tighten their borders even further. This caused increased tension on the continent. Doubts regarding the merits of a unified European labour market were increasing. The second wave of nativist populism in Europe thus rose to a significant degree in response to an anticipated integration with post-communist Eastern Europe in the wake of the collapse of the Berlin Wall.

The dramatic changes around the collapse of communism and the dissolution of the Soviet Union also opened up a new space in the conspiratorial milieu in the West. For a long while, the Soviets had been presented as the main enemy of the West, and many tales of evil deeds by the Eastern bloc had thrived during the Cold War. With the opening of the Iron Curtain the arch-enemy of the West was suddenly gone-had vanished into thin air. As will be examined further, this led to a vacuum which was increasingly filled by new mutual suspicions between East and West.

\section{The Rise of the Second Wave}

In this chapter I will examine several cases where nativist populism rose in the second wave. Amongst the most prominent in Western Europe were the Flemish Block in Belgium and the Pim Fortuyn List in the Netherlands. This was also the time of the flamboyant Silvio Berlusconi in Italy and Jörg 
Haider in Austria. It was likewise in the second wave when Pia Kjærsgaard was able to turn her Danish Peoples Party into one of the most influential in Denmark. Even in West Germany the far-right Republican Party polled around 11 per cent in 1992.

The ugly ducklings from previous eras were showing their faces again; fascism, racism, xenophobia, nationalism, separatism, and so on. As I will discuss in this chapter, this was also the time of more rogue ultra-nationalist movements, even of neo-Nazi movements.

Years later, doubts about European integration were also growing on the Eastern side. In fact, dominant parties in several of the new EU member states were to turn against Europeanization, often indeed-as I will discuss further in the following chapter-on a highly nationalist ground, such as in Hungary and Poland. As result, Europe was unknowingly entering into an era of renewed polarization with growing mutual animosity.

This wave could be separated into two phases: Before and after the terrorist attacks in the US on 11 September 2001. The horrendous event brought increased validity for mainly anti-Muslim sentiments, which spread more easily into the mainstream than before the heinous event. Still, here I deal with the entire period as a single wave. Although its two parts should also somewhat be considered separately, for the purpose of this book it is more useful to treat $9 / 11$ as a fundamental shift within the second wave.

\section{Sneaking Past the Social Democrats}

By the 1990s the once-strong links between social democrats and the working class were rapidly evaporating. After the collapse of the communist bloc many social democratic parties in Europe went looking for new kinds of voters and seeking more lucrative alliances in the political centre-in what was branded the new economy-even in some places toying with neo-liberal economic policies.

Social democratic parties who were founded by workers and their representatives had throughout the twentieth century been in close connection with working people. Gradually, however, leadership of these parties started to become filled instead with well-educated political professionals. Surely, many of them were descendants of those that had founded these parties, but increasingly the newer leaders had themselves little personal experience of manual labour. 
Over time, this new leadership began to imagine that there was no longer any working class, that the importance of manual labour had diminished. Indeed, on the surface, society had evolved to the extent that the traditional blue-collar workers could no longer as easily be seen on the streets as before.

This, however, was always a fundamental misunderstanding. Although the tasks of workers had changed, the nature of labour had not. The working class might not fill factories in as large numbers as before, still, they could be seen all around in society; clerks in shops, bus drivers, waiters and barmaids, people manning the tellers in institutions, day-care personnel, and so on. The working class are quite simply all those people who live hand to mouth, those who survive from one pay cheque to the next and run into financial difficulties if missing only couple of payments. In other words, the working class is still most people.

However, instead of focusing primarily on the standard of living, of raising wages and on worker's rights, the new social democratic leadership was becoming increasingly occupied with newer and more sophisticated political tasks; such as of gender equality, administrative practices, democratic innovations, higher education and environment protection. In the UK for instance, the Labour Party under the leadership of Tony Blair geared up in this direction and was rebranded as 'New Labour'. The traditional social democratic strongholds in Scandinavia were also severely hit.

As result, social democratic parties were by the late twentieth century losing the support of the blue-collar working class throughout Europe. Many of the traditional working-class voters on the left felt politically alienated. As will be illustrated in the following pages, this change allowed nationalistic populists to sneak past and fill the vacuum.

\section{Chávismo}

Over in Latin America, populists were in this period also surging on both sides of the left/right political spectrum. Alberto Fujimori's main initial task when seizing power in Peru in 1990 was in defeating the socialist revolutionaries in the movement Shining Path. Two years after coming to power Fujimori killed off Congress and ended the fragile Peruvian democracy. In other words, Fujimori pulled a similar stunt of eroding democracy by way of democratic elections in Peru, as later was somewhat mirrored in Eastern Europe during the third wave, which I will discuss further in the following chapter. 
After a decade in power, Fujimori fled to Japan under accusations of corruption and human rights violations. On the other side of the political spectrum, Hugo Chávez came to power in Venezuela in 1998 on the canopy of the Bolivarian Revolution. ${ }^{1}$

Chávez was a political outsider who campaigned against a corrupt domestic elite. He promised to build a new authentic democracy, by the people and for the poor people, for instance by tapping into the country's rich oil wealth. Chávez rose to power via democratic means. It was not until 2003 that he started to abandon democratic processes for more authoritarian rule. In 2006, the Chávismo regime had grown fundamentally repressive, for example by eliminating term limits, locking up disobedient officials and exiling many opposition voices.

\section{Flanders Field}

When walking down the winding path into Ypres near the French boarder in northern Belgium to visit the War Memorial of the Flemish town, I recall finding it hard to imagine its dark history. The restaurants encircling the now peaceful main square paved in medieval stone were filled with lively patrons enjoying their steamed mussels and chilled white wine, and not necessarily even contemplating the horrors that the fields all around had witnessed in two terrible world wars. This is where opposing armies had dug their trenches in World War I, reaching from Dunkirk on the northern coast and all the way down to the Swiss Alps. I could not escape feeling the weight of history when listening to the brass band playing under the town's arch gate in commemoration of the fallen.

Were it not for the linguistical duality-Ypres in French, Ieper in Flemish-it might be difficult noticing former partitions. Here is where Julius Caesar ran into intricacy in conquering Gaul. And here is where Napoleon had to retreat from Waterloo in Wallonia for his final battle. Many of the young men who gave up their lives still lie in some of the 170 cemeteries in the area. On 13 October 1918 Adolf Hitler was injured here in a gas attack by the British army. Years later he brought back his troops of the Third Reich. The devastations all around the now tranquil town of Ypres was one of the triggers behind the European integration process. Instead of sacrificing young men on battlefields, officials would assemble in stuffy rooms in Brussels, merely one hundred kilometres away, forced to suffer bad coffee until settling their disputes. In light of this history, the 
surge of Dutch nativist populism in Belgium, and in the neighbouring Netherlands, carries a magnified meaning.

Amongst those finding support in the second wave was the Flemish Block in Belgium (Vlaams Blok-VB, later renamed Vlaams Belang), based on a previous Flemish nationalist movement that had campaigned for an independent Flanders. Belgium is a federal state, consisting of Dutch-speaking Flemish people, French-speaking Wallonians and a very small enclave of German speakers. The capital, Brussels, is in a particular situation. Although most of its inhabitants are French speakers it is a bilingual separate Belgian capital region with its own Parliament. In addition, Brussels is the principal seat of the European Union, and thus in effect a highly internationalized metropolis.

Being among only very few 'white on white' xenophobic political parties in Europe, the Flemish Block argued that Flanders was subsidizing Wallonia too much, and sought to break up the Belgian state. Its electoral breakthrough came in the 1991 general elections, when winning 6.6 per cent of the vote. The party, though, only stood in Flanders, where it won 12 per cent. Although sharing the populist space with couple of smaller and more narrowly focused parties, the VB steadily grew in Flanders. The party found increasing support in subsequent national elections. The Flemish Block rose to new heights in the 2003 election, when landing almost 12 per cent of the overall vote, before-for a while-again seeing diminished support.

The VB simultaneously suffered from two contingent difficulties. One was a prolonged Cordon Sanitaire that other parties had encircled around it, steadfastly refusing co-operation despite their increasing share of the vote. Although the unifying boycotting of the mainstream served as a useful narrative for attracting voters in the short term, it turned into an obvious disadvantage in the long run. As result of being so firmly kept away from power, the VB saw diminished electoral support. Generally, people don't want to throw away their vote, and can grow frustrated with supporting a party that can't get any of its policies through.

The VB also faced growing competition. The populist ground was becoming increasingly crowded with many movements of a similar ilk standing in elections. The VB was squarely nationalist in their populism. This is in line with the shift from the neo-liberal emphasis of the first wave to a more nationalist focus within the populist realm in the second wave. In addition to its Flemish nationalism, the VB was highly xenophobic, anti-immigrant, social conservative and authoritarian on issues relating to 
law and order. Their Catholicism was for instance illustrated in fear of moral decay and an emphasis on protecting traditional family values, as well as in opposition to abortion and homosexuality.

The VB was never very anti-European, presumably due to EU membership widely being accepted in Belgium, even celebrated. On the socioeconomic axis they were centrist, perhaps rather welfare chauvinist than neo-liberal. This is similar to related parties in the Nordic countries, who I will examine more closely later in this book.

Although the VB was never a one-man show like many other populist parties have tended to be, it still benefitted from one of its two main leader's oratorical skills, Filip Dewinter.

The VB accused the established parties in Belgium of trapping the public within bad policies based on political correctness, for instance by silencing legitimate concerns people might have over multiculturalism, which was fast emerging in Belgium. Jan Jagers (2006) argues that the VB wanted to break up a 'conspiracy' of the mainstream against the ordinary people, and that it positioned itself as the 'only defenders of the silent majority, the popular will and democracy'.

It can be argued that the VB based its nationalism on an Herderian understanding of the Flemish nation, as being permanently distinct from other groups within the Belgium state. As Pauwels (2013) notes, this ethnic nationalism is emphasized in the VB's pursuit for intra-Flemish homogenization in Flanders. Viewing a Flemish nation as so firmly separated is furthermore in line with what Friedrich Meinecke referred to as Kultur-nation. The VB's call for an independent Flemish state is thus based on an ethnopluralist ideology of decisive separation between nations. Initially this call for homogenization was aimed against Walloons contaminating Flanders, but gradually, their aim was refocused and turned against non-European immigrants, mainly in opposition to Muslims.

\section{ForTuyn's Liberal NovelTy}

Liberalism had always been a significant part of the domestic political identity in the Netherlands. Correspondingly, post-war populist actors started out from a position of protecting the Dutch socio-liberal heritage. Its first populist to find significant success was the extravagant Pim Fortuyn. His liberal flair separated him from most others of the field in the second wave. 
Although political dividing lines between Catholics and Protestants had been quite sharp in the Netherlands, there was perhaps not much that divided the major parties when it came to principal understandings of the government's place in economy and society. The fundaments around the political consensus of the mainstream were first challenged in 1994 when an ethno-nationalist party won seats in parliament, paradoxically named Centre Democrats. The party soon disintegrated, but only after having left the Dutch with a new appetite for populist politics. In its wake, several such parties stood in municipal elections around the country. After this period of activity a party called Liveable Netherlands (Leefbaarheid) was established in 1999.

The flamboyant figure Pim Fortuyn soon emerged as its leader. Fortuyn parted from most other populist leaders in his ostentatious lifestyle. Paul Lucardie and Gerrit Voeman (2013) described him as being theatrical and almost exhibitionist in his homosexuality. In fact, Fortuyn was in his own way prototypical for the open, tolerant and social liberal Netherlands.

Fortuyn was a prolific orator and he was able to articulate his opposition to multiculturalism in an exuberant style, which fitted well within the Dutch political culture. He warned against creeping Islamization, which would for instance be to the detriment of homosexuals and other outgroups that enjoyed freedom in social liberal Netherlands. He insisted that Islam was a hostile religion which posed an extraordinary threat to Europe.

Fortuyn was adamant in placing himself on the side of Dutch liberalism. When criticized for xenophobia regarding North-African immigrants he once famously responded. 'I have nothing against Moroccans; after all, I've been to bed with so many of them' (qtd in Ascherson 2002).

\section{BerlusConismo}

Italian politics have for long been a hotbed for all kinds of populism. Their flavour and style have varied greatly, travelling the distance from fullyfledged fascism to, for instance, a leftist anti-elite version. In many ways, as I discussed above, the fascism of the interwar years in Europe was born in Italy. The 1980s then saw a rise of authoritarian separatists in the north, the Northern League (Lega Nord-LN).

When swiftly seizing authority in 1994, Silvio Berlusconi sent a shockwave through both Italian and European politics. Rising to power on the second wave of post-war nativist populism, Berlusconi resembled the antitax populist leaders of the first wave, such as Le Pen in France and Glistrup in Denmark. 
In the third wave, his flamboyant style was then also somewhat mirrored in the rise of several rogue strongman outsiders, most clearly by Trump in America-who, as I will discuss in the following chapter, bears much resemblance to Berlusconi. The two were starkly alike. Both were businessmen and rogue political outsiders. They could be classified as anti-politicians, positioning themselves as strongmen alternatives to the failing political class. Both were widely ridiculed in the media, but both also proved to be quite teflonic to scandal. In fact, they got away with behaviour that would ruin most other politicians. Instead they functioned as a tool for the ordinary public to 'stick it' to the political establishment.

Laying the ground domestically, Berlusconi also paved the way for other and more outright populist parties to take control in Rome in the third wave, as for example when Lega and the Five Star Movement (M5S) joined in a coalition in 2018. This particular heritage of Berlusconism travelling from the second to the third wave will be tackled further in the following chapter.

When entering politics in 1994, Berlusconi was a rich and flamboyant businessman, a media tycoon owning many of the country's most popular private TV stations, as well as the AC Milan football club. In other words, his business was in providing what the common people wanted to watch. Rumours were afloat that one of his main incentives for entering politics was to avoid prosecution for tax fraud, which he feared was underway by the authorities.

Like many other populist politicians, Berlusconi had no experience in politics. He was a political novice. Instead of travelling the traditional route, rising through the ranks of an established political party, he founded his own, the Forza Italia, meaning Go Italy! In bypassing established norms of political campaigning, Berlusconi exploited his position as media tycoon. For instance, he had his TV stations relentlessly running both his advertisements and promoting his political ideas in their programming. No other candidate came anywhere near to enjoying such privileges.

Berlusconi would furthermore promise anything that he though the people wanted, regardless of prospects of being able to make good on his word. In 1994 he promised to create one million new jobs. After the election, Berlusconi was able to scrape together a coalition and became Prime Minister. However, his government collapsed only three months later. His comeback came in 2001 and he governed until 2006. Prior to the 2001 election, Berlusconi led a campaign coalition and offered what he called a contract with the Italians, among other things promising to cut unemployment by half. 
Berlusconi was an authoritarian strongman leader. Still, in his flamboyant and capricious behaviour, he could be quite amusing and charismatic. His unorthodox manner, for a politician of his era, also attracted attention abroad. The international media was branding his politics as Berlusconism (Orsina 2014). Initially the term held positive connotations, linked to optimism and laissez-faire entrepreneurism. However, with increased controversies around him, the term got tainted, and, in the end shifted the meaning to populism, scandal, corruption and demagoguery in governance.

Berlusconi departs from many populists of today. When it came to coalition building, he proved to be a skilful political craftsman. He was for example able to build bridges to both the neo-fascist Allenza Nazionale and Lega Nord. Both those parties were populist, but they were not really on speaking terms with each other.

\section{The Northern League}

As stated above, the populist field in Italy is vast. The heritage of Benito Mussolini's fascism was for instance kept within the Italian Social Movement (Movimento Sociale Italiano-MSI). Its leader, Gianfranco Fini, however described the party as post-fascist, rather than neo-fascist (Griffin 2000). The MSI joined Berlusconi's government in 1994. Selfdescribed post-fascist, Fini became Deputy Prime Minister and Foreign Minister and he moved on to preside over the Italian Chamber of Deputies.

Among the most influential nativist populist parties in Italy was the Northern League, a far-right separatist party founded by Umberto Bossi in the early 1990s as a federation of regional movements in the north of Italy. The complete name is indicative of its politics: The Northern League for the Independence of Padania. Initially their primary target was the corrupt political elite, which they referred to as 'thieving Rome'.

It was the NL that brought down Berlusconi's first cabinet in 1994, after abandoning the coalition. Reports say that they resented seeing many of their supporters, and even some parliamentarians as well, defect over to Berlusconi's party. Leading up to the 2018 parliamentary election its name was shortened to only Lega. As I will discuss in the following chapter, the party entered a coalition government in 2018 with the leftist populist Five Star Movement.

The LN came to master a communicative technique that was later a trademark of many populist politicians. In delivering their highly 
controversial messages, Bossi and his fellows bypassed the media and started instead to address the public directly, through rallies, speeches, posters and banners. Lorella Cedroni (2010) branded this style as communication without media. Their language of rupture and threat would spur pushback and, thus, bring them attention. Cedroni explains how Bossi and his associates were able to tap into the language of the ordinary people and apply it in politics.

The highly controversial contributions of the NL generally attracted greater media attention than other politicians usually enjoyed. Their rough and demagogic rhetoric, that often carried insults and other kinds of provocation, would indeed be spread through society via the media criticizing their disruptive language-which might be somewhat ironic for the fact that they were so prone to bypass the media.

As I will discuss further in the following chapter, the NL has since been transformed from emphasizing regionality to a more general Italian nativist populism, perhaps most similar to the National Front in France.

\section{Haider's Tabloid Populism}

As I discussed in the previous chapter, both the Peoples Party of Switzerland and the Austrian Freedom Party were retuned in a populist direction during the first wave of post-war nativist populism. It was during the second wave in the 1990s that these parties found significant electoral success. In 2004 for instance, the Swiss Peoples Party came into government.

In Austria, Jörg Haider steered the Freedom Party to become perhaps the most influential in the country. Haider was energetic and charismatic. $\mathrm{He}$ was especially skilful in tapping into the fears and emotions of the ordinary public, while avoiding the more intellectual debates.

The key to his success was found in coupling with the country's tabloid media, mainly the influential daily, the Kronen Zeitung, by far the most widely distributed daily in the country. Both party and paper united in defiance against elite, for example turning against the established serious media elite. This recipe was to become rewarding for populists throughout Europe; charismatic leaders backed by the tabloid media, relating to ordinary publics fears of the foreign rather than participating in intellectual political debate.

Twice Governor of Carinthia in Austria, Jörg Haider rose through the ranks of the FPÖ and was its leader from 1986 to 2000. Through the 1990s, the FPÖ found increasing support in many municipal elections. Its 
greatest national electoral success came in 1999 when winning almost 27 per cent of the vote and becoming the second largest party in parliament. Subsequently the FPÖ formed a coalition government with the mainstream Austrian Peoples Party (ÖVP). After coming to power, the FPÖ saw fast diminishing support. This is in line with populists often having difficulties maintaining their support after coming into positions of power.

Haider was an exuberant leader. He was surrounded by a group of likeminded young men, often referred to as the Bubelpartie, or boy-gang. Amongst them was Heinz-Christian Strache, who became party leader in 2005-as I will discuss further in the following chapter. As I mentioned in the previous chapter, Haider retuned the FPÖ away from its pan-Germanic nationalism and towards a more particular Österreichpatriotismus, meaning Austrian patriotism. The party programme of 1997 was titled 'Contract with Austria'. It emphasized unified interests and a preference for a single Austrian nation.

The FPÖ found greatest support in the wake of the Iron Curtain coming down. Austria's geographical proximity to the Balkans led to a flow of refugees and asylum seekers rushing across its borders. The FPÖ led the opposition against this sudden flow of migrants who were competing for jobs with Austrians. In the early 1990s, the foreign-born population in Austria surpassed 10 per cent. The FPÖ problematized migrants as both a threat against the county's culture and as a burden on its economy. Reinhard Heinisch (2013) points out that racist and xenophobic rhetoric was also included when pointing particularly to immigrants as major cause of crime in Austria.

Haider's influence reached far beyond Austria's borders. In many ways he paved the way for the softer and more acceptable versions of right-wing populist parties around Europe. This has been labelled the Haiderization of politics, the process of normalizing previously condemned views, such as racism, by way of coded rather than explicit xenophobia (Wodak 2015).

\section{Austria First}

In 1992 the FPÖ published its programme 'Austria First', declaring that Austria was not and would not become a country of immigration. They especially opposed Muslim migration, stressed protecting the country's Christian heritage and values, and emphasized upholding law and order. At the time, this was mainly aimed against those coming from the Balkans and Turkey. In the early 1990s, Haider insisted that the 'social order of 
Islam is opposed to our Western values'. He said that human rights and democracy were incompatible with the Muslim religious doctrine. 'In Islam, the individual and his free will count for nothing; faith and religious struggle-jihad, the holy war-for everything' (qtd in Merkl and Weinberg 2003).

Perhaps strangely for his anti-Islam rhetoric, Haider was criticized for fostering friendly relationships with notorious Arab dictators, such as with Saddam Hussain in Iraq and Muammar al-Gaddafi in Libya. He was even accused of receiving significant sums of money from Saddam Hussain (Mikbakhsh and Kramar-Schmid 2010).

Haider was shrewd in accommodating the concerns of the blue-collar public and he was able to multiply his party's support among low-skilled labourers. The FPÖ was even finding greater support from lower-income people than the Social Democrats enjoyed.

The most controversial aspect of the party's discourse was its apparent anti-Semitism and tendency to dismiss and defend Austria's Nazi past. Haider was criticized for frequent praise of Austrian Second World War veterans, even for former Nazis that had served in the Waffen-SS. He declared that that they were decent people of good character who remained true to their convictions. He was also accused of Holocaust denialism. In a 1991 debate, an opponent criticized Haider's plan of bringing down unemployment by calling it reminiscent of Nazi policies. Haider replied by saying: 'No, they didn't have that in the Third Reich, because in the Third Reich they had proper employment policy, which not even your government in Vienna can manage to bring about.'

Initially the mainstream parties in Austria had tried to isolate the FPÖ. That strategy was abandoned by the ÖVP in 2000 when accepting them into a coalition government. Haider himself was deemed to be too controversial to assume the office of Chancellor, a position he otherwise should have been able to claim given that his party was the largest in the coalition. The government was thus instead led by ÖVP leader Wolfgang Schussel. Haider also stepped aside and ceded leadership of his party to Susanne Riess-Passer who became Vice-Chancellor. Although formally outside of government, Haider was still seen to have great influence on it.

Allowing far-right populists into government caused outrage to many of Austria's partners in the European Union. The Cordon Sanitaire which had been upheld around Western Europe in the post-war era, of keeping right-wing extremists at bay and away from power, had been breached. The EU responded by taking measures against Schussel's government, for 
instance by ceasing co-operation with the Austrian government. In September 2000 the EU abandoned its diplomatic sanctions. The entire episode is noteworthy as years later similar kinds of populists would rise to power in several other EU countries, such as in Hungary, Poland and for a while in Italy, as I will examine further in the following chapter.

After ceding control in the FPÖ, Haider became increasingly at odds with the new leadership. In 2005 he broke away and formed the Alliance for the Future of Austria. Jörg Haider died in a car crash in 2008.

\section{The No-Queen of Denmark}

In Scandinavia, nativist populism was also being remodelled during the second wave. With Mogens Glistrup the founder of the Progressive Party running into increasing trouble, the position of Pia Kjærsgaard was growing stronger. While she had been toning down Glistrup's harshness and was shrewdly reformulating the party's policies in a more socially acceptable manner, the hardliners in the party wanted to stick to their old ways of uncompromising anti-politics. The two sides ultimately clashed during the 1995 party congress when Kjærsgaard's pragmatic faction lost. Subsequently, she left with three of the party's MPs in tow to form the Danish Peoples Party (Dansk Folkeparti-DF), which domestically was to become one of the most influential right-wing populist parties in the world. The name chosen was the same as that of an authoritarian semifascist party of the 1930s.

In the 1998 general election, the Danish People's Party towered above the Progressive Party, winning 7.4 per cent of the vote. By carefully crafting her message to become more socially acceptable, Kjærsgaard's DF was fast moving into the mainstream, toning down Glistrup's anti-tax rhetoric, but still maintaining hardcore anti-immigrant policies. The DF campaigned against Denmark becoming multi-ethnic and what it called foreign infiltration. Gradually they increased their anti-immigrant discourse while downplaying the libertarian rhetoric. In economic term, the party moved much more into the middle ground, for example emerging as a staunch defender of the Danish welfare state. Anti-immigration was becoming the core to the DF's politics, claiming that migrants were threating the welfare system, which the party vowed to protect.

Similar to the FPÖ in Austria, the DF firmly insisted that Denmark was not, and had never been, an immigrant country, forcefully emphasizing 
that Denmark should not evolve to become a multi-ethnic society. This set the tone for the party's politics for the coming years.

Despite the move of the DF in a more mainstream direction under Pia Kjærsgaard, wide societal acceptance was still not in sight. In late 1999, then Social Democratic Prime Minister, Poul Nyrup Rasmussen, for example, famously stated that Kjærsgaard and her clan would never be 'house-trained' (stueren). This prediction was fast proved to be monumentally wrong, when the turn of several events soon played to the DF's advantage.

The first was the referendum on adopting the Euro in September 2000. The Danish Peoples Party had already laid the groundwork in 1997 when campaigning against the EU's Amsterdam Treaty, mainly in playing on fears of mass migration from Eastern Europe. It ran on the slogan 'Vote Danish, Vote No'. Most of the mainstream parties supported adopting the Euro, but the DF aggressively campaigned against abandoning the Danish currency, the Krone. Pia Kjærsgaard's relentlessness on the issue earned her the title of the 'No-Queen of Denmark'. When the public indeed refused the Euro, she and her party won much-needed legitimacy and the result underpinned their claim of speaking on behalf of the people (for folket) against the unified elite, which, it maintained, was out of touch with the ordinary Dane.

The second event to play to the DFs advantage came in the wake of the terrorist attacks in the US on 11 September 2001, which many in Denmark took as validation of the DF's harsh anti-Islam stance-which I will return to discussing later in this chapter.

\section{Moving Against Migration}

Theorists analysing populist politics have long had difficulties with classifying the Norwegian Progress Party. Although the initiator, Anders Lange, had belonged to the quasi-fascist Fatherland League before the Second World War, and even though he had gone as far as voicing support for Apartheid in South Africa, he never campaigned on an anti-immigrant platform-it was simply not a pressing political issue at the time in Norway. In fact, Lange forcefully denounced being linked to racism. The FrP was established as a neo-liberal anti-establishment movement rather than nationalist, protectionist or even fully anti-immigrant. Only later on did it emerge to embrace these qualities while simultaneously phasing out its formerly strong neo-liberal stance. 
The Norwegian Progress Party was not even fully Eurosceptical, which has been regarded as a common feature of nativist populist parties in Europe. In fact, both Lange and Hagen in 1972, and Hagen again in 1994, voted for Norway's EU accession. The party was split on the issue and only more recently under the leadership of Siv Jensen did it lean further to the No-side, though officially it still remained undecided. In other words, the party was thus constructed out of quite a few contradictory elements.

In the second wave of nativist populism, Carl I. Hagen was clearly steering the party towards the centre, to become perhaps the softest version of populist right-wing parties in Europe. Still, similarly to Denmark, the focus was shifting away from tax reduction towards concerns over Norway being turned in a multicultural direction.

In the early 1990s, the FrP was festered by rivalries between different internal factions. This was a fiercely fought ideological dispute between a libertarian faction on the one hand, and on the other a nativist populist faction, together with a smaller Christian conservative faction. The libertarians were pro-EU, positive regarding migrant workers but critical of the state-funded Church. They were thus almost the polar opposite of the two other factions-bar them all wishing to lower taxes and in promoting private enterprise.

In a dramatic party congress in 1994, the liberal faction lost influence over to the more nationalist Christian conservatives. The FrP's position was moved to protecting Norwegian culture against foreign influences and preventing the welfare system from being exploited by immigrants and asylum seekers. Furthermore, the party turned hostile to the Sami ethnic minority in Norway, for example in a resolution calling for the Sami Assembly being dissolved.

In a classical welfare chauvinistic way, the new mantra of the party was in putting 'our people first'. The party found a way to square this new nativist welfare emphasis with their low-tax heritage by proposing using oil money to fund it. Another sign of the move away from socio-liberalism towards a more authoritative direction was found in a new emphasis on law and order, for example, in arguing that the system favoured criminals over their victims. Anders Jupskås (2013) documents a change in the party's programme, focusing mainly on immigration, criminality and care for the elderly. The immigrant issue was gradually to take up more space in the party's programme and discourse, until it came to the forefront of its agenda. 


\section{The US Ultra-Right}

The Norwegian Progress Party is among the mildest versions of NeoNationalist parties discussed in this book. Several violent ultra-nationalist movements also existed in many countries. Although they largely fall outside of the scope of this book, mentioning some them briefly is of benefit for understanding the breath of nativist populism.

In America, for instance, many violent survivalist nationalist movements have influenced political debates. Most notorious is the white supremacist group, the Ku Klux Klan. Surely, these kinds of groups are out on the furthest fringes of far-right extremism and their actions resonate in no way with non-violent nativist populists. Their extremism is much rather comparable to violent radical-left terror groups in Europe in the 1970s, and contemporary Islamist terrorists. Still, both the violent and milder versions tended to tap into similar political and philosophical sources. This perhaps corresponds to how the violent left tapped into socialist literature, and Islamist terrorists based their horrific deeds on mainstream religious texts.

The story of Timothy McVeigh who blew up the US federal building in Oklahoma in 1995 is telling for the belief system in some of these movements, as his was just one of many violent acts conducted in the name of a good fight against evil domestic authorities. McVeigh repeatedly quoted and referred to white supremacist literature. He belonged to an antigovernment survivalist militia, which, after the fall of communism shifted from warnings of Soviet conspiracies to ones aimed against the US federal government. For example, they insisted that US President Bill Clinton's campaign for gun control was a 'prelude to tyranny' (Russakof and Kovaleski 1995).

Gradually, McVeigh came to believe in a series of anti-government conspiracy theories and he visited Area 51, where he believed the government was hiding evidence of UFOs. In a letter to his childhood friend Steve Hodge prior to his action, he pledged his allegiance to the constitution of the USA and accused the government of having betrayed the founding fathers, and that it should be punished accordingly. He wrote: 'I have come to peace with myself, my God and my cause. Blood will flow in the streets, Steve. Good vs. Evil. Free Men vs. Socialist Wannabe Slaves' (qtd in Serrano 1997).

Timothy McVeigh's attack, commonly referred to as the Oklahoma City Bombing, killed 168 people and injured hundreds more. He 
committed the domestically-grown terrorist attack in revenge for the federal government's handling of the Waco siege in Texas in 1993 where seventy-six followers of the Christian sect the Branch Davidians died, including their leader David Koresh. In letters to his sister Jennifer, McVeigh seemed convinced that the government was plotting a dictatorial New World Order, and that they had already waged war against his people. McVeigh believed that his survivalist movement was under government attack, insisting that he himself was merely a soldier responding to the hostility and defending his country from the government oppressors (ibid.).

Timothy McVeigh was a frequent listener of the conspiracy theorist Milton William Cooper, an Oklahoma-based radio show host who entangled UFO-ism with anti-government conspiracy theories. McVeigh was also plugged into the same network of Christian patriot movements such as the so-called Hutaree, a Michigan-based militia. Members of the paramilitary group believed that the federal government and various law enforcement agencies were all tangled up in a New World Order conspiracy, which the Hutaree pledged to stop. In preparation for an endof-time-battle with the authorities, the Hutaree declared themselves 'Christian warriors'. Referring to the coming of an Antichrist they wrote: 'The Hutaree will one day see its enemy and meet him on the battlefield if so God wills it' (qtd in Schaeffer 2011).

In 2001, Timothy McVeigh was sentenced to death for the Oklahoma City bombing. In 2012, several members of the Hutaree were arrested and prosecuted for planned violent attacks against government agents.

\section{$9 / 11$}

At 8:46 on Tuesday morning 11 September 2001, a Boeing 767 passenger plane en route from Boston Logan airport to California flew into the north tower of the World Trade Centre in downtown New York City. Seventeen minutes later another plane hit the south tower. At 9:37, a Boeing 757 aircraft penetrated the Pentagon building in Arlington near Washington DC. The fourth and final plane crashed into a field in Pennsylvania after passengers' revolted against the hijackers. Collectively, this was the deadliest terrorist attack in world history, killing 2996 people and injuring over 6000 others. $9 / 11$ also proved to have the greatest effect of any terrorist act in human history. 
The perpetrators were identified as being the Islamist terrorist organization Al Qaeda, under the leadership of Osama Bin Laden, established after the Soviet Union invaded Afghanistan in 1979. Nineteen men, most of them from Saudi Arabia, and also the United Arab Emirates, Egypt and Lebanon, carried out the act.

As I have discussed before in this book, cultural polarization between the Christian West and the Muslim Middle East had been growing with greater mutual animosity. While the previous divide between the liberal democratic West and the communist East was closing after downfall of the Berlin Wall, another polarization was separating the Christian sphere from the Muslim world. The increasingly conflictual relationship between the two religious spheres was for example evident in repeated invasions of US-led militaries in the Middle East, such as in the Gulf War of 1990. In his famous previously mentioned writings titled The Clash of Civilizations, Samuel Huntington maintained that after the collapse of communism, Islam would emerge as the main ideological adversary of the West.

Despite this growing acrimony, most Americans were on 11 September 2001 wholly taken by surprise. Many sought explanations of why Muslims, in general, hated them. This is what Tim Aistrope (2016) described as an 'Arab-Muslim paranoia narrative'. A similar rhetoric had existed prior to the attacks, such as in the writings of authors like Bernhard Lewis (1990), who searched for 'the roots of Muslim rage' when explaining antiAmerican hostility in the Arab world. Lewis maintained that this hatred, at times, went beyond hostility and 'becomes a rejection of Western civilization', which, indeed, is 'seen as innately evil', and those who promote or accept it as the 'enemies of God'.

Similar sentiments were also flourishing on the other side of the divide. In a video released by Osama Bin Laden on 27 December 2001, when justifying the heinous terrorist act, the Al Qaeda leader discussed what he called the West's hatred of Islam. He linked it to the crusades of previous times and said that the West in general, and America in particular, 'have an unspeakable hatred for Islam'. ${ }^{3}$

\section{Freedom Fries}

9/11 was of monumental importance not only for the USA but also for the entire world. The response to it was also fast and far-reaching. The US government not only invaded Afghanistan, and later Iraq, in an endeavour that was branded as the War on Terror, but domestically they also moved 
to uproot many fundamental aspects relating to individual and civil rights. The so-called Patriot Act profoundly changed people's rights to privacy, providing authorities with much greater powers to bypass civil liberties in order to prevent future terrorist actions. The legislation was criticized for eliminating judicial oversight of the security apparatus, and for instance permitting the National Security Agency (NSA) to eavesdrop on private communications (Eggen and Vandehei 2006). The Patriot Act seriously limited people's individual liberties.

The terrorist attack led to a massive spike in nationalist sentiments, and it also fuelled anti-immigrant sentiments. Through its ripple effects, the Alt-Right in the US was finding much more fertile ground than before. It can safely be concluded that without $9 / 11$, the mechanics of the Patriot Act would never have passed through Congress. Interestingly, the erosion of individual freedom that was brought with the Patriot Act was justified by being in the name of freedom. Rhetorically, freedom became the buzzword in DC. Illustrative for this turn, was for example when the canteen in Congress changed the name of French fries to freedom friesin a snipe against France which had opposed the US-led military quests in the Middle East.

Many within George W. Bush's administration had belonged to the Neoconservative faction of the Republican Party, which I discussed in the previous chapter. The Bush administration had taken a hard turn to the right and abandoned most bipartisan attempts. In line with their hawkish foreign politics, their instinct was in taking immediate tough action. This led for example to the invasion into Iraq on 19 March 2003, even though no reliable evidence indicated that the Iraq government, or even any individual Iraqis, had been involved in the attack.

The aftermath of $9 / 11$ saw a wave of hate crimes rising against Muslims in America. Numerous incidents of harassment and violence were reported around the country, including attacks on mosques and religious leaders. Hateful acts included assaults, arsons, vandalism, threats and also several killings. Surveys showed that people of Middle Eastern origin felt discriminated against and were being targeted (Iyer 2001). Anti-Muslim sentiments were now wide-spread, reaching far beyond the shadow communities where racism had always thrived. Domestic opposition to the War on Terror was often dismissed as being unpatriotic and even treasonous. Influential extreme-right radio host, Ross Limbaugh, for example went so far as to link critical Democrats to Al Qaeda (see in Levitsky and Ziblatt 2018). 
Almost instantly all sorts of conspiracy theories cropped up. One was created by Donald Trump. In an TV interview on ABC, Trump insisted that Muslims in New Jersey had been celebrating the downfall of the Twin Towers on the other side of the Hudson River that Tuesday morning (see Kessler 2015). This was, though, never true.

The most common and persistent conspiracy theory around 9/11 insisted that US President George W. Bush and British Prime Minister Tony Blair knew about the attacks in advance and let them happen. This is significant as conspiracy theories were in the aftermath of the event being penetrated further into the mainstream than perhaps ever before in contemporary history (see Bergmann 2018). In fact, there is now a vast and far-reaching literature widely available in mainstream circulation solely devoted to questioning official accounts and offering alternative versions of events on that Tuesday morning. A pseudo-academic Journal of 9/11 Studies has for instance proved to be a vehicle for the mainstreaming of views that continue to offer alternative accounts of what really happened.

In line with this trend, one David Ray Griffin (2006) has for example insisted that the event was a false-flag operation, concocted by the Bush administration to provide justification for invading Afghanistan and Iraq. Others, for example Peter Dale Scott (2013), drew similarities between $9 / 11$ and the John F. Kennedy assassination, classifying both as what he called 'deep events'. Those, he said, were events that the mainstream media avoided and were only studied by scholars of what he referred to as 'deep history'.

For a decade, $9 / 11$ and its aftermath dominated the US political agenda. It can be argued that only after Osama Bin Laden was killed in May 2011, could Americans move away from allowing the event to contaminate almost all domestic politics. It is in no way overstating the issue, when arguing that the attacks brought a fundamental shift in the sort of populist politics examined in this book.

9/11 did not only mark a turning point in US politics. The horrible event also had far-reaching effects in Europe, where populist parties were indeed fast claiming legitimacy by pointing to their previous warnings against the evil of Islam. Islamophobic prejudice was spreading around the Western world. In Austria, for instance, Jörg Haider proposed that the EU should from then on only accept asylum seekers from Europe. 


\section{The Anti-Muslim Turn}

The 9/11 terrorist attacks brought the White Genocide conspiracy theory, which I discussed in the previous chapter, back to the forefront. This notion of cultural replacement has since echoed loudly within many antimigrant far-right movements on both sides of the Atlantic. Cas Mudde (2016) illustrates how right-wing populists in Europe have been especially successful in depicting Muslim migrants as external threats to the benign native society. In this depiction, Muslims are generally portrayed as a homogeneous group of violent and authoritative religious fundamentalists, who are pre-modern and primarily anti-Western in their politics.

Chris Allen (2010) defines islamophobia in Western societies as the negative positioning of Islam and Muslims as the 'other', posing a threat to 'us'. The archetypical Muslim is, indeed, not only portrayed as inferior, but also as being alien. Anti-Muslim sentiments of this kind have widely become normalized in the West. Muslims are frequently 'featured as invaders', often viewed as part of a 'coordinated plan to conquer Europe' (Kinnvall and Nesbitt-Larking 2010).

Inhered in the theory is an apocalyptic view of Muslims dominating and destroying a liberal and democratic Europe. This intention is generally attributed to all Muslims, irrespective of whether or not they are religious or at all in support of Islamization in the West. As result, those that advocate for multiculturalism and peaceful coexistence can then be accused of naivety and/or of betrayal.

Several influential publications have warned of an Islamist conspiracy of occupying the West. American writer Bruce Bawer (2007)—who later moved to Norway-describes his feelings when arriving in Amsterdam in 1997 as having found the closest thing to a heaven on Earth, that he was finally able to escape the American Protestant fundamentalism. The book titled While Europe Slept-How Radical Islam Is Destroying the West from Within describes how he watched Western Europe gradually fall prey to another and much more alarming fundamentalism, that is, to Islam. In a tale of external replacement, Bawer insists that the ever-so-tolerant Europeans were being invaded by intolerant Muslims. Here, Bawer follows a similar intellectual path as Pim Fortuyn did in the Netherlands, that in order to defend Europe's social liberalism, it is necessary to prevent Muslims from contaminating these societies.

This fear of subversion is only the first part of the full theory. Its completion usually also takes the form of accusing a domestic elite of betraying 
the good ordinary people into the hands of the external evil. Here intentionality is applied, maintaining that covert malevolent powers are bringing about mass migration. This is a core message in the immensely influential book titled Eurabia-The Euro-Arab Axis. Writing under the pen name of Bat Ye'or (2005) (in Hebrew, daughter of the Nile), its author Giséle Littman maintains that a particular group of politicians and media people in France were already well on their way to handing the continent over to Muslims. Littman argued that ever since the 1972 Oil Crisis the European Union had secretly conspired with the Arab League to bring about a Eurabia on the continent. She said that Europe was now fast being Islamicized and becoming a political satellite of the Arab and Muslim world.

Writer Oriana Fallaci (2006) picked up on this same argument and claimed that Muslims were, in fact, invading and subjugating Western Europe through a combination of immigration and fertility. She wrote that they 'have orders to breed like rats' and stated that these 'eternal invaders rule us already'. She concluded that this was the 'biggest conspiracy that modern history has created'.

\section{The Tides Turn in Eastern Europe}

After the collapse of communism and the downfall of the Iron Curtain most countries in Eastern Europe embarked on a quest of implementing a Western-style liberal democracy. Joining the EU was seen as a vital milestone on that road. In a way, it was seen like rejoining the wider European family of states and drawing a line in the sand behind their communist past. However, only few years later, when the rosy promise of fast growth and wide-reaching prosperity was failing to materialize soon enough, some of the countries in Eastern Europe started to move away from liberal democracy. The second wave of nativist populism was also a time of rising authoritarian nationalism throughout Eastern Europe in the wake of the collapsed communist model. Most notorious was ethnic cleansing in the Balkans, discussed at the beginning of this chapter.

In the eastern part of the continent, nationalism was never deemed being as derogatory as it was in Western Europe in the post-war era. Parties of the populistic and nationalist ilk were rising throughout the former communist bloc, such as the Slovak National Party, which was established already in 1990. In Poland, the Kaczynski brothers rose to power with their party Law and Justice. Lithuania similarly saw rise of their 
version named Order and Justice. In many countries, the rise of the nation was seen in contrast to foreign dominance, and thus, as a source of pride.

The voyage of Fidesz, who came to dominate politics in Hungary, is particularly interesting. The party was founded in 1988 by young democrats opposing communism. In the beginning, Viktor Orbán and his compatriots celebrated liberal democracy. They wanted to join the European Union and promoted both social and economic liberalism. Correspondingly to that, the Fidesz party joined the international political federation of liberal parties in 1992.

With the collapse of communism, civil society was fast forming. Free media were reporting. NGOs were operating. Academia was liberated from state control. And soon the Hungarian economy was growing. In a way, Hungary was a poster-child for Eastern Europe's return to liberal democracy. It was only after electoral losses in 1994 that the Fidesz party started its gradual move towards conservative attitudes. Its travel towards more authoritarian tendencies however caused serious splits within the party, with the liberal faction eventually leaving or being silenced. Still, even in his first term as Prime Minister, from 1998 to 2002, Viktor Orbán kept firmly within traditional democratic boundaries.

At the time, it was rather the much more militant Jobbik movement that was promoting authoritarian nationalism. Their message at the time was always contaminated with many of their members blatant flirtation with full-blown neo-Nazism.

\section{Claiming Victimhood}

After losing power in 2002, Orbán blamed the liberal media. When winning authority again in 2010 , Fidesz had transformed to become fully nativist populist. As I will discuss further in the following chapter, the party has since been accused of abandoning ideals of liberal democracy, to the point of Hungary approaching becoming an autocracy (Schwarz 2018).

One of the main moves of both Fidesz, and the then more rogue Jobbik-movement, was in elevating Hungarian nationalism, mainly by emphasizing the majestic spirit of Magyar King Saint Stephen who lived around the year 1000. Their view of history emphasizes the continuous victimhood of Hungarians by invading armies of Mongols, Ottomans and lastly the Austrian Habsburgs. They would dwell on Hungary's bad fate at Trianon in 1920, when they lost two-thirds of their land and 60 per cent of the population (Judis 2018). 
Bringing back the glory of Magyar times was appealing to many Hungarians, while national sentiments were also nurtured by pointing to ongoing threats of foreign dominance. As analysed throughout this book, nativist populism points simultaneously to external threats and internal traitors. In the case of Orbán's Hungary, the external threat was first seen to be the EU, and later migrants. Interestingly, Hungarian-born billionaire George Soros was placed in a precarious hybrid role of both external threat and internal traitor. Although an American citizen, Soros became an important figure in Hungarian business and society after the collapse of communism. He bought up many assets and sought to influence Hungary through his Open Society Foundation. The foundation was tasked with building up aspects of civil society based on liberal democratic ideals.

George Soros for example established the Central European University in Budapest, which became a bastion of both liberalism and multilateralism in international relations. Although Orbán had started out as a beneficiary of Soros, when accepting a Soros scholarship for his studies in England he later turned against him. Gradually, Soros was turned into one of the main targets of nativist populists in both Europe and in America, with many conspiracy theories floating around of his vast-reaching influence. I will return to discussing some of them in the following chapter.

\section{The Kremlin's Oligarchic Reform}

Over in Russia, Vladimir Putin was also slowly moving away from the path leading towards liberal democracy, which had been marked by Boris Yeltsin after the dissolution of the Soviet Union in 1991. Yeltsin's shock-therapy economic reform, including en masse privatization, far reaching deregulation and instant devolution of the currency, led to uncontrollable inflation and wide scale unemployment. Between 1991 and 1998 the Russian economy had contracted by almost half. This led many to equate liberal democracy with hardship accompanying Yeltsin's laissez-faire policies.

While the public at large was suffering, many of Yeltsin's cronies were among those able to exploit the havoc and accumulate state property for rock bottom prices. A band of fantastically wealthy oligarchs was emerging out of the nomenklatura. When Vladimir Putin came along, many Russians had grown frustrated with the apparent injustices around the so-called reform process, which only seemed to benefit those close to the Kremlin elite. 
Putin viewed the collapse of the Soviet Union as having been a geopolitical disaster. He has thus strived to resurrect Russia to its former glory, not on a Marxist-Leninist ground as before, but instead based on nationalist ideals. Putin's path towards almost total dominance in Russia was initially paved when striking a deal with many of the country's wealthiest businessmen. In exchange for their loyalty, he would not interfere in their wealth accumulation. Those that did not comply, however, ran a risk of finding themselves incarcerated-like for instance Mikhail Khodorkovsky, who headed the Yukos oil giant. Instead of Yeltsin's wild and violent oligarchic capitalism of the 1990s, Putin turned onto a path of both managed market economy, and, indeed, towards state managed democracy.

After taking office, Putin sought close co-operation with the West. He spoke fondly of the European Union and attended a NATO summit. Reinstating stability brought him popularity. Putin's initial move away from liberal democracy came in the wake of the Chechen War. After successfully squashing the rebels, Putin moved to drowning out dissident voices around this fantastically vast country, for instance by gradually taking control of much of the media. His hard-line actions eventually brought him to collide with the international community, which was growing increasingly concerned with human rights violations in Putin's Russia.

With the collapse of the Berlin Wall, the pendulum in many Eastern European countries had swung fast from socialism to far-reaching neoliberal policies. This was a period of great instability, and in the early new century many of these same countries were rapidly returning to authoritarian patriotism. As I will discuss further in the following chapter, both in Hungary under Orbán and in Russia under Putin, liberal democracy was being eroded via the incremental implementation of slowly evolving authoritarian rule.

\section{Geopolitical Shifts in France}

By the 1990s, the initial rise of the National Front in France had somewhat receded and the party had also consolidated, enjoying the support of above one-tenth of the population. Several shifts were occurring in the second wave of nativist populism which served to broaden its appeal.

The Cold War saw a move from polarizing tension primarily between socialism and liberal capitalism towards confrontation on another axis. The new axis was contrasting cosmopolitanism with the protection of national values. Similar to changes made by Pia Kjærsgaard in Denmark, in catering to geopolitical shifts accompanying the collapse of communism, 
Jean-Marie Le Pen was also starting to downplay the FN's neo-liberal economic position. Instead, he emphasized an anti-immigrant rhetoric. In this period the FN was moving both from neo-liberalism to protectionism, and from promoting European economic integration to campaigning against it.

In line with conventions in French politics, it was expected that the right-of-centre President Jacques Chirac would in the second round of the 2002 presidential elections compete against the Socialist Lionel Jospin for control of the Élysée presidential palace. Surprisingly however, Jean-Marie Le Pen narrowly surpassed Jospin and manoeuvred his way into the runoff. This sent a shockwave down the spine of French politics. And it proved to be a watershed moment. Not only was this significant for French politics, but for populist politics in Europe more generally, which was clearly mounting much more wide-reaching support than before.

Le Pen proved to be especially skilful in riding the wave of post 9/11 anti-Muslim sentiments. In the wake of several violent incidences in France, the 2002 presidential debate largely revolved around law and order. The FN campaigned on a zero-tolerance platform, insisting on much tougher punishment, even of introducing the death penalty. Le Pen successfully linked immigration to increased crime and positioned mainly Muslim migrants as being a 'mortal threat to civil peace' (qtd in Shields 2007).

Jean-Marie Le Pen's rise to significant electoral success coincided with the before-mentioned demise of social democracy. Le Pen had indeed been highly successful in recruiting support from the working class, from the traditional Socialist Party base. After having amended his previously held neo-liberal policies he instead catered to many people's concerns of migrants stealing their jobs, as well as overburdening the welfare system.

Policy changes like these were surely important, but accompanying discursive alterations were also of significance. Although the FN was increasingly focusing on immigration, James Shields (2007) illustrates how its path to success only became clear when simultaneously repackaging the political message into a more refined rhetoric.

Another political change came when Jean-Marie Le Pen turned against Europeanization; for instance, in campaigning against the Euro and what he called the euro-globalism of the Maastricht Treaty which he claimed was ruining ordinary peoples livelihood (Magali 2013). In the 2005 referendum on the EU's Constitutional Treaty the FN campaigned against it. Le Pen described the European Union as being a totalitarian antidemocratic structure. 
While Le Pen was turning against the EU, he was-interestinglysimultaneously cultivating a cosy relationship with several authoritarian world leaders. This was similar to Silvio Berlusconi in Italy and Jörg Haider of Austria. Like Haider, Le Pen for example fostered a friendly relationship with Saddam Hussain of Iraq.

\section{National (and European) Identity}

This turn against social liberal and a culturally diverse Europe is in line with writings of several intellectuals of the identitarian movement, who viewed that identity is the element distinguishing one set of people from another. In his book Why We Fight: Manifesto of the European Renaissance, Guillaume Faye (2001) for instance warned that diluting the biocultural identity of the European people would erode European civilization. He thus argued for Europe returning to ethnic consciousness and said that it was necessary to 'defend the biological and cultural identity of one's own people'.

Jean-Marie Le Pen never went as far as Fay did. Still, he identified many enemies of the people. They included immigrants, the domestic elite both in politics and media, and foreign agents. Collectively these actors were painted as posing a threat not only to peoples' prosperity, but also to the very French identity. The FN now also positioned itself as the primary defender of French sovereignty and national identity. They endorsed protectionism and consolidation of state authority. Their programme called for inner expansion by for example promoting pro-birth policies (Magali 2013).

The 2002 presidential election was the first occasion that a far-right populist qualified to the second round in France. The political establishment though, was not willing to fully accept Le Pen's legitimacy. Jacques Chirac refused to face Le Pen in traditional televised election debates, which were cancelled. Socialist Party supporters found themselves forced to back their arch-rival, solely to prevent a far-right populist to be handed the keys to the Élysée palace in Paris. In the run-off, Chirac received an unprecedented 82.2 percent of the vote. In other words, the French voting public staunchly rejected Le Pen's populist stance at the time. He was never able to escape his controversial past. Similar to Jörg Haider in Austria he was accused of being a Nazi sympathizer (Shields 2007).

Fifteen years later however, when his daughter Marine Le Pen repeated her father's success and faced Emmanuel Macron in the presidential 
run-off in 2017, the mood had altered. As I will discuss further in the following chapter, she received much greater support, and, in effect, won almost full acceptance as a serious candidate standing on an equal footing to her rivals.

\section{Neo-Fascist Movements}

The second wave of nativist populism in Europe also saw the rise of a few more rogue and even neo-fascist movements. One of the most influential parties of that kind was the hooligan British National Party (BNP). Founded in 1982, the BNP started out as being firmly far-right neo-fascist and basing its politics on biological racism. They saw the Anglo-Saxon race as being superior to others. Matthew Goodwin (2011) defines it as an extremist far-right party. Initially, the BNP was kept far out on the fringe. However, it drew attention in society around its marches and rallies and through its more militant factions, such as the paramilitary Combat 18, which was created for protecting their events from anti-fascist protesters. The name Combat 18 refers to Adolf Hitler's name.

The BNP rose to renewed prominence in the early 2000s under the leadership of Nick Griffin, who had resumed power by the turn of the century. Griffin set out to broaden the appeal of the party and move it away from its neo-Nazi roots. For instance, by replacing biological racism with ideas of more culturally based ethno-nationalist segregation, stressing the cultural incompatibility of many different racial groups, Griffin was able to significantly increase the BNP's electoral support, especially in municipal elections in north and eastern England. Its greatest win came in 2009 when receiving one million votes in the European Parliamentary elections and sending two MEPs across the English Channel.

On a premise that migration from far-away was undermining British society and culture, the BNP called for an end to non-white immigration. Initially the party advocated compulsory expulsion of all non-whites from the UK, but after Griffin assumed power, they called for voluntary removals. Another change accompanying Griffin's regime was that their previous anti-Semitist stance was exchanged with Islamophobia. In the wake of the $9 / 11$ terrorist attacks, the party launched what it called the 'Campaign Against Islam'. The BNP viewed Islam, as such, as posing a threat to 'our British culture' (Woodbridge 2010). This even related to those that they referred to as 'mainstream Islam'. 
The party insisted that every Muslim in Britain was a threat to the country. After the 7 July 2005 London bombing by Islamist terrorists Griffin referred to Islam as an 'evil, wicked faith' (qtd in Copsey 2009). He went on to describe Islam as a 'cancer' that needed to be removed from Europe through 'chemotherapy' (qtd in Trilling 2013).

After coming to reign over the party, Nick Griffin sought to foster relationships with like-minded parties elsewhere in Europe. He was for instance heavily influenced by Le Pen's National Front in France, and he also tapped into the anti-Islam ideology of the French Nouvelle Droite, which I discussed in the previous chapter. In 2004, Jean-Marie Le Pen of the National Front was the guest of honour at a BNP-hosted event which they called the Anglo-French Patriotic Dinner. Griffin also sought co-operation with the Hungarian Jobbik movement, and with the Italian Forza Nuova.

Domestically, the boundaries between the many nationalist movements were somewhat blurred. Many BNP members were for instance involved in the notorious English Defence League led by Tommy Robinson, who formerly had been an BNP activist.

Gradually the BNP saw diminished support, which coincided with the rise of the more benign looking UK Independence Party, which I will discuss further in the following chapter.

\section{Neo-Nazi Movements}

Some of these movements were fully neo-Nazi, such as Denmark's National Socialist Movement, which was founded under the leadership of Jonni Hansen in 1991, based on the old Danish Nazi Party of the interwar years.

When I was living in Copenhagen in the latter half of the 1990s, the neo-Nazis were flying high in the national media. They would also hold rallies, marching on the streets in full Nazi insignias, openly celebrating Adolf Hitler and Rudolf Hess. I once interviewed Jonni Hansen for an Icelandic news magazine. Their headquarters were located in a barricaded villa on the Western outskirts of Copenhagen. Hansen received me in their radio studio, where they broadcasted white supremacist heavy metal music in-between enunciating their openly racist political messages. I remember him telling me that their main source of income was in selling Nazi memorabilia to like-minded compatriots in Germany, as merchandise of that kind was forbidden south of the border. 
Nativist populist parties were much later to find significant success in Sweden than in most of the neighbouring countries. However, several nationalist - and also a few far-right and extremist movements-had thrived on the margins of Swedish politics throughout the post-war era. The Sweden Democrats-which I will discuss more closely in the following chapter-was founded in 1988 out of the remains of movements closely associated with neo-Nazi forces (Bergmann 2017). Its first proper leader, Anders Klarström, had for example been involved in the Hitleradmiring Nordic National Party formed in 1956.

The Sweden Democrat's international secretary and perhaps main ideologist was Mattias Karlsson. He described the party's quest in quite combative terms, saying that Christian nations in the West were in an 'existential battle for our culture's and our nation's survival (qtd in Becker 2019). The SD, thus, was in the beginning much closer to the skinhead scene and had a much more extreme and xenophobic legacy than nativist populist parties in the other Nordic countries.

\section{Defending Dutch Liberalism by Opposing Islam}

Prior to the rise of the Pim Fortuyn List, criticism of the emergence of a multicultural society was almost a taboo in the Netherlands, a critiquing that was not considered as being politically correct. As a homosexual, Fortuyn was able to criticize Islam from a position of protecting the Dutch social liberal order. He accused Islam of being culturally backward and medieval, and, thus, a threat to the open and tolerant lifestyle of the Dutch nation. For the time and place, however, Fortuyn's sharp criticism of Islam caused him to be expelled from his party the Leefbaarbeid in 2002.

Fortuyn responded with establishing his own party, and in his name, the Pim Fortuyn List. He insisted that his new party's primary errand was to bring power back to the people from corrupt politicians. His main rhetorical contribution to the wider field of nativist populism, was, however, his discursive novelty of shifting away from the traditional authoritarian tendencies of most populists, to positioning himself as the defender of Dutch liberalism, fighting against a threat that was emanating from culturally and socially intolerant Islam.

Aikin to others of a similar ilk, Fortuyn's relatively moderate populism had a clear nationalistic side to it. But his emphasis on social liberalism placed him apart from most other populist leaders at the time. However, as I will come back to in the following chapter, this repositioning of the 
populist message, the protection of the West's liberalism against authoritarian Islamism, was to be mirrored by several nativist populists in the third wave, for instance in the Nordic countries.

In May 2002, less than two weeks prior to general elections, Fortuyn was killed in Amsterdam by a left-wing animal rights activist. The Pim Fortuyn List surged in the wake of his death, winning 17 per cent of the vote, and becoming the second largest in the country. The party entered government but soon lost credibility.

Out of its ruins, Geert Wilders was able construct his Dutch Freedom Party (Partij voor de Vrijheid-VVD) and, as I will document in the following chapter, emerged as one of the most vigilant and successful populist leaders in Europe. Wilders broke with traditional democratic structures. The party remained his own enterprise, and he did not even invite its parliamentary candidates to join it. In 2006, Wilders entered parliament with nine seats. Later his party came to support the government in return for implementing some of its policies. Wilders was a pioneer in adopting a new populist winning formula, in combining socio-economic left-wing views with hard-core right-wing conservative socio-cultural ideas (Lucardie and Voerman 2013). Wilders based some of his politics on Fortuyn's socio-liberalist heritage, but he was soon to steer his party in a much more traditionally authoritarian direction in its opposition to multiculturalism, readmitting to the mix a more generic anti-Muslim rhetoric.

\section{Berlusconi's Scandals}

In Italy, Silvio Berlusconi was quick to jump on the wagon of the post-9/11 anti-Muslim rhetoric. He insisted that Western civilization was 'superior to Islamic culture'. In its wake, Berlusconi was able to push through stricter immigration policies, including for instance the Bossi-Fini law in 2002 , named after his two populist coalition partners. The new legislation provided for the expulsion of illegal immigrants. It was criticized in the European Parliament for being too restrictive and severe. ${ }^{5}$ In the 2008 general election, he described jobless foreigners as an 'army of evil' (qtd in Fekete 2018).

Berlusconi staunchly supported US-led military endeavours in response to the $9 / 11$ attack, such as the Iraq invasion. The Italian Prime Minister became cosy with many of the more rogue strongman leaders of his time. For instance, he had good relationships with Muammar al-Gaddafi in Libya and with Recep Erdoğan in Turkey. Although both were Muslims, 
Berlusconi was still slowly abandoning Italy's long-lasting political partnership with the Arab world. Instead, he turned to backing Israel and enjoyed his close relationship with Israel's Prime Minister, Benjamin Netanyahu, who he declared was a great leader. In response, Netanyahu called Berlusconi one of Israel's greatest friends. ${ }^{6}$ Berlusconi was adamant in maintaining an especially good working relationship with US President George W Bush, and he also fostered a particularly close friendship with Vladimir Putin of Russia. He even reached out to Alexander Lukashenko, the authoritarian leader of Belarus.

Berlusconi's political career was raked with a series of scandals and blunders. He was accused of bribery, abuse of office and of links to the Mafia. There were also several sex scandals around him, including accusations of sleeping with under-age prostitutes. For years the Italian taxman was on his heels, in investigations which Berlusconi dismissed as being an anti-democratic communist witch-hunt against him. In his defence, he once called on supporters to form a freedom army, some kind of civil militia, to come to his aid in defiance against his prosecutors.

As I discussed before, post-war nativist populists have usually refrained from celebrating fascist leaders of the interwar era. Still, Berlusconi repeatedly revealed his ill veiled admiration of Benito Mussolini, describing him as a good leader who only by mistaken loyalty to Adolf Hitler had signed up to exterminating the Jews. Berlusconi insisted that Mussolini 'had been a benign dictator who did not murder opponents but sent them "on holiday" (qtd in Owen 2008).

In total, Berlusconi served nine years as Prime Minister, making him the longest serving premier in post-war Italy. During his reign, Berlusconi was able to push through several policy changes, undermining the free civil society in Italy. Under his rule, freedom of the press was found to be backsliding. A Freedom House report in 2004 detected increased media concentration in Italy, where 'political pressure led to the downgrading of the country from "free" to "partly free"'? The report said that Prime Minister Silvio Berlusconi had been able to exert undue influence over the public broadcaster RAI. 'This further exacerbates an already worrisome media environment characterized by unbalanced coverage within Berlusconi's enormous media empire.' The Economist writer David Lane (2005), found that Berlusconi in effect controlled 90 per cent of all national television broadcasting in the country.

In the field of populist leaders, Berlusconi stands out in many ways. He never completely fitted the profile of the fully-fledged nativist populist. 
Still, both his rhetorical style and governance he had a clear populist side. He was prone to offering lofty promises. He would also dismiss the elite and insist that he himself was directly linked to the people. Bobba and Legnante (2016) maintain that Berlusconi was able to turn elections into referendums on himself, rather than allowing them to revolve around the state of governance. However, despite these clearly populist qualities, Berlusconi can also be defined in many other ways. As such, he does not completely qualify as being counted among the contemporary European extreme-right. Rather he should be defined as a centre-right quasi populist.

\section{FINDING LEGITIMACY}

When I moved to Copenhagen for my postgraduate studies in 1996, Danes were still flaunting their socio-liberal side. Pia Kjærsgaard was still largely dismissed as a rogue demagogue that would never find influence. This was, though, fast changing. The $9 / 11$ attacks in the US brought new support for the Danish Peoples Party. Most people in the mainstream had consistently and firmly opposed the DF's anti-Muslim politics and the party was harshly criticized for flirting with racism. That was drastically altered after the horrendous $9 / 11$ event. Similar to the significance of the 1973 so-called 'earthquake elections' the 2001 election broke new grounds in Danish politics. First, the DF was gaining legitimacy and was from then on positioned as one of the permanent parties in Danish politics. Secondly, immigration had since become perhaps the country's most salient political issue. After moving away from the anarchist past of the Progress Party, Kjærsgaard was able to present herself and the DF as a credible alternative to the established parties.

For many, the $9 / 11$ terrorist attack served to validate the DF's criticism of Islam. The sudden change boosted confidence among the party's candidates in the coming parliamentary elections held only several weeks later. Mogens Camre, DF representative in the EU Parliament, described Islam as 'ideology of evil' and suggested that Muslims should be 'driven out of Western civilization' (qtd in Klein 2013). He maintained that Muslims could not successfully be integrated into Danish society and that they had indeed come to take over Denmark. Camre said that all Western countries had been 'infiltrated by Muslims', and that even though many of them spoke nicely to us 'they are waiting to become numerous enough to get rid of us' (qtd in Sommer and Aagaard 2003). In reaction to the terrorist attacks the election campaign came to revolve around immigration, and the DF surged. 
Many of the mainstream parties soon started to follow the DF's line on immigration. A relatively widespread consensus emerged on the need to stem migration and to impose stricter demands on the integration of foreigners, and of adherence to the Danish way of life. Anti-immigrant politics was becoming mainstream. The debate no longer revolved around the validity of a tougher migration policy, but rather on its means and methods.

A competition thus emerged as to who was the toughest and most credible on migration. Subsequently, immigration was the most covered political topic in media. Roemer and Van der Straeten (2004) found the Danish media to be nationalist and racist in its reporting on immigration, and prone to reproducing a discourse that legitimized ethnic inequalities. In covering migration, the Danish media emphasized crime, social problems and conflict with Danish society (Stainforth 2009).

\section{DANISHNESS}

The DF skilfully rode the rise in anti-Muslim sentiments after $9 / 11$, and they were able to set the agenda in the elections. Their anti-immigration rhetoric revolved around three main themes: cultural infiltration, criminality and welfare abuse. One of their election campaign posters asked: 'Your Denmark? A multi-ethnic society with gang rapes, repression of women and gang crimes. Do you want that?'

Anders Jupskås (2015a) found the DF being especially successful in linking other political issues to immigration, such as welfare, the state of the economy and anti-elitism. Immigration was also directly linked to gender issues, maintaining that Islam was incompatible with the level of women's liberation in Denmark. In that regard, the veiling of women in Islam became a central and symbolic issue.

Securing 12 per cent of the vote in the 2001 election and becoming the third largest in the country marked the long and successful journey of the DF from the cold fringe and into the very core of Danish politics. The party's new position of power was cemented when subsequently backing a minority government of Venstre and the Conservative Party led by Anders Fogh Rassmussen. Over the coming decade the DF was able to push through restrictions on immigration, tightening demands for integration, implementing tougher measures on crime with stricter sentences, and increased public welfare for the elderly.

In the DF's 2002 principal manifesto, culture was in addition to ethnicity found to be core to Danishness (Danskhed). This culture was defined 
as 'the sum of the Danish People's history, experience, religion, language and common customs' ${ }^{8}$ The manifesto for example stated that Denmark should belong to the Danes. The party argued that immigrants were parasites on the Danish welfare system, which, as result would be severely weakened - to the detriment of ethnic Danes, when in need of services.

The youth movement went further. In a 2003 advertisement, it for example linked Muslims with mass rapes and gang criminality. Gradually, the DF's rhetoric became the dominant political discourse on migration and Muslims. Arguing that cultural racism had found especially fertile territory in Denmark, Karen Wren (2001) maintains that the absence of a significant counter rhetoric has also become institutional and part of the very fabric of Danish society. Even many on the left flank of Danish politics came to accept the anti-immigrant discourse, as I will document in the following chapter.

The Danish Peoples Party grew to become perhaps the most influential in the country, rapidly becoming one of the largest in parliament and prolonging its position of power when repeatedly backing right-of-centre governments. Denmark came to implement one of the toughest legislations on immigration in Western Europe. Criteria around eligible refugees were narrowed, and foreigner's rights tightened. Rights to family reunifications were reduced, to the extent that foreign spouses younger than twenty-four years were no longer allowed residence with their Danish husbands or wives. Asylum seekers faced stricter demands, including passing a tough test on language, society, history, culture and values (for more, see Widfeldt 2015).

While the DF surely pushed the hardest for these tough measures, the other right-wing governmental parties proved to be quite willing participants in the quest. The combined measures had the effect of significantly reducing the influx of non-EU immigrants.

\section{Conflicts And Connections}

These troubled immigrant relations only came to international attention in 2005 when the established broadsheet national Danish daily, JyllandsPosten, commissioned several cartoonists to mock prophet Mohammed in drawings published in the paper, causing rage among many Muslims. Karen Wren (2001) argues that cultural racism in Denmark is distinctly anti-Muslim. The DF was successful in demonizing Muslims and in portraying them as invaders. 
The provocation with the cartoons was said to be intended to underline freedom of speech as a fundamental value but many saw it as being Islamophobic and racist, even revealing ignorance of the historical impact of Western imperialism.

The Danish People's Party has been connected to many other nationalist movements in Denmark. Similar to France, where the right-wing populist think tank Nouvelle Droite was indirectly linked to the National Front, the Danish Association (Den Danske Forening -DDF) served as an important intellectual source of ideological inspiration for the DF. Anders Widfeldt (2015) argues that the association had, for example, provided the party with their three-fold argument against immigration; first as a threat to Danish culture and ethnic identity, second, as a cause of crime, and third, as a burden on the welfare state. Pastor Søren Krarup was perhaps their most prominent and articulate spokesman. He said that love of fatherland and the nation-state was one of the loveliest human emotions, closely connected with honesty and decency (qtd in Wren 2001).

The Danish Association viewed Denmark as being a homogeneous Christian nation-state, where migrant workers could only be guests. The continuous presence of foreigners was seen as a threat. In this light, the DDF was instrumental in framing the Danish Peoples Party's argument within an ethno-pluralist narrative, based on the doctrine that even though nations were equal they should be kept separate. Although this discourse derives from fascist traditions, the DF was able to steer it away from the stigma of discredited ideologies such as neo-Nazism.

The DF was adamant in avoiding being linked to the more controversial nationalist movements, for example the before-mentioned Danish neo-Nazi movement, Danish Front or the Danish Forum. DF members have, in fact, been expelled for being associated with these radical movements.

\section{Milder Norwegians}

Although populist politics started out on a similar platform in Norway as they had done in Denmark, the Norwegian Progress Party evolved to become a much milder version of their counterparts. Its leader Carl I. Hagen always argued that his party was very different from the DF. He made a firm legitimizing distinction when emphasizing that he was not criticizing the immigrants themselves, but rather the soft and lenient immigration policy of the Norwegian Labour Party. 
Still, the development of the two parties was in a similar direction. Anniken Hagelund (2003) explains how the FrP moved from problematizing migration merely on economic grounds to also voicing concerns of its effect on Norway's culture. The party argued that in order to prevent ethnic conflict in Norway, immigration and asylum sought from 'outside the Western culture complex' had to be stemmed. 9 This was a classic nationalist ethno-pluralist doctrine, emphasizing the importance of keeping nations separate, without openly claiming any sort of superiority.

Carl I. Hagen argued that non-Western immigration would bring a culture of violence and gang mentality. Concerns over its effect on the ethnic composition of the nation were increasingly voiced, for example, in a clever way of quoting former Conservative Prime Minister, Kaare Willoch, who once warned against 'too rapid changes in the unified character of our population' (qtd in Hagelund 2003).

Almost from the outset, the FrP found greater acceptance in society than similar parties had enjoyed in most other countries. Already in the 1980s the FrP was within a majority position when supporting state budgets. It thus found legitimacy much earlier than its many counterparts in neighbouring countries. In the period from 1985 to 2001 they held the balance of power between the left-wing and right-wing blocs in Norwegian politics.

By the turn of the millennium, the FrP had become the largest force in some opinion polls. In addition to applying Herbert Kitschelt's winning formula, discussed before, of combining right-wing populism with authoritarianism and a policy of anti-immigration, its success can be attributed to Carl I. Hagen's ability to keep out more extreme forces. By the turn of the century, he set out to purge the party in a series of expulsions of far-right radicals.

By ousting extremists, the party was able to move closer to the power centre of Norwegian politics. In exchange for supporting the right-ofcentre government, Hagen was able to secure the influential parliamentary position of chairman of the Committee of Finance for his deputy, Siv Jensen, who was later to succeed him as party leader.

\section{Brave Truth-Tellers}

While the FrP firmly refused to be associated with racism their representatives positioned themselves as brave truth-tellers, defying the political correctness of the ruling class. In 2005 the party published a poster depicting 
a juvenile of foreign descent pointing a gun at the viewer. The text stated that 'the perpetrator is of foreign origin'. When criticized for its xenophobic undertone, the party spokesman said that it was simply necessary to 'call a spade a spade' (qtd in Jupskås 2015b).

The anti-immigrant position of the FrP was based on a new master framework where immigrants were presented as an economic burden and a cultural threat, rather than being biologically inferior (Rydgren 2007). Anders Hellstrom (2016) documents how the immigration issue gained salience in the party's repertoire in the 1990s, when warning against the danger of cultural heterogeneity. He says that immigration was in that way 'transformed from an economic to a cultural issue'.

Anders Jupskås (2015b) identifies five distinctive narratives that defined the FrP's anti-immigration platform. First, that immigrants cost too much. Second, that they exploit 'our' welfare. Third, that they are more prone to crime than the native population. Fourth, that they undermine the Norwegian way of life. And lastly, that they challenge Norway's values, mainly liberal values. Thus, when combined, that they threaten Norway's economy, welfare system, security, culture and liberal values.

Jupskås documents that the first two frames were present from the outset, that the second two narratives emerged in the 1980s but that the last one, regarding the challenge to liberal values, was only presented after $9 / 11$. In any event, it is clear that the cultural emphasis in the antiimmigrant rhetoric, that is, on rules, norms and values, only emerged to prominence in Norway in the 1990s. Simultaneously, the importance of the economic frames gradually decreased.

\section{ETHNo-Nationalist NorWay}

Immigrants were not the only population that Progress Party spokesmen portrayed as an out-group in Norway. To a large extent, the same applied to the indigenous Sami population living in northern Norway, as well as in neighbouring Sweden and in Finland. The FrP sought to diminish Sami influence and for example proposed dissolving the Sami Assembly (Sametinget) (Iversen 1998).

Despite the FrP's move to distance itself from the Danish People's Party, it still adopted many of their neighbours' policies on immigration; for example in cutting foreign aid and in proposing the mandatory expulsion of foreigners sentenced to jail for more than three months. They furthermore emphasized much stricter rules on family reunifications, 
including the notorious twenty-four-year-old minimum rule for spouses, and eighteen-year-old maximum rule for children.

Their anti-immigration rhetoric gradually grew more distinctively antiMuslim. Already in 1979, Carl I. Hagen described Islam as a 'misanthropic and extremely dangerous religion' (qtd in Jupskås 2013). Since then, their anti-Islam rhetoric has grown firmer. Muslim immigration was linked to terrorism, forced marriage and crime (Bergmann 2017). Mulisms were portrayed as a burden on the welfare system and as a threat to Norwegian culture. The FrP furthermore identified a need to fight against Sharia laws filtering through into Norway. In the third wave of nativist populism, discussed in the following chapter, the Norwegian Progress Party was fast moving to become fully accepted in the wider society and landed for the first time in government, in a coalition with the centre-right.

\section{UnQuiet Tea Party}

The so-called Tea Party faction within the American Republican Party was formed in response to Barack Obama running for president in 2008, becoming the first African American US head of state. Although the Tea Party might be placed in the third wave of nativist populism, I still discuss it here, as the movement was in many ways better aligned with politics operating before the end of the second wave of nativist populism.

The Tea Party advocated for small government and lowering of taxes. The name refers to a pivotal moment in the American Revolution in 1773, when English tea was dumped into the Boston harbour in rebellion against British taxation. Their mantra was: no taxation without representation. The anti-tax emphasis of the Tea Party resembles, perhaps, the neo-liberal populist parties in Europe of the first wave, such as Mogens Glitrup's Progress Party in Denmark, Anders Lange in Norway and the initial rise of Jean-Marie Le Pen's National Front in France.

The Tea Party was not only fiscally conservative, it was also fundamentally socially conservative. Most of its members emphasized Christian traditional family values, tighter security, and they opposed amnesty for illegal immigrants. They rallied in protection of the right to gun ownership, but forcefully campaigned against women's rights to abortion.

The Tea Party was largely funded by the Koch brothers, Charles and David, who in the 1980s had established a political group called Citizens for a Sound Economy. The group's mission was to fight for less government, lower taxes and less regulation. Its first chairman was the libertarian 
congressman Ron Paul, who three times sought the presidency of the US. Partially, the Tea Party was born out of his failed presidential bid in 2008. The Tea Party would field fringe candidates to challenge those they branded being Republican establishment candidates.

The Tea Party can also be seen a successor of the Neoconservative movement of the 1970s, discussed in the previous chapter. For instance, Neocon leader Newt Gingrich, the former Republican Speaker of the House of Representatives, was among its influential ideologues. Correspondingly, the Tea Party believed in a similar kind of American exceptionalism as the Neocons had done the 1970s. They promoted the aggressive protection of US interests around the world. Both the Neocons and the Tea Party based much of the politics on religious nationalism and indeed on science denialism, which later proved to be a vicious cocktail, as I will discuss in a later chapter when dealing with Donald Trump and, for instance, his response to the Coronavirus Crisis of 2020.

Another forebear of the Tea Party's policies was Pat Buchanan. Interestingly for Donald's Trump's harsh stance on immigration much later, Buchanan's presidential bids in the 1990s were largely based on his claim that if 'we do not build a sea wall against the waves of immigration rolling over our shores' then America will 'become a Third World country' (qtd in Berlet 1999).

\section{American Conspiratorialism}

In a norm-breaking manner for what had been customary in American politics up until then, many Tea Party members emerged as leading voices in criticizing Barack Obama and questioning his legitimacy as US President. Several anti-Obama conspiracy theories were spreading at the time. First, a relatively insignificant story was sailing at full mast; that he was not born in the USA and, thus, not legitimate as president. The story, without even any crumb of evidence, soon gained a surprising following.

One of these stories insisted that Obama was an agent for instating a 'one world government' (see Judis 2018). Many conspiracy theories were afloat insisting that Obama was secretly a Muslim. In an email campaign in 2007 it was stated that he had attended a radical Wahhabi school in Indonesia. Another story insisted that he had taken his oath of office for the US Senate by swearing on the Quran (Holan 2007). Never mind the well-established fact that Obama was a Christian and that he visibly took the oath of office on a Bible. Stories of this kind, even though utterly-and 
indeed provably—bogus, still had their effect. In a 2010 poll, almost onefifth of responders believed that Obama was, indeed, a Muslim. ${ }^{10}$

In one version, Obama was not only accused of being a Muslim, but also a communist. Iowa Congressman Steve King said that Obama was anti-American and that he would lead the country to becoming a 'totalitarian dictatorship' (qtd in Terkel 2008). Perhaps the most far-fetched story insisted that he was, in fact, the Antichrist (Posner 2008).

These anti-Obama conspiracy theories were not only being spread from the far-right. Suspicions of this sort were also being fed by his mainstream opponents. Even some fellow Democrats, who supported Hillary Clinton, flirted with such tales in hope that it would bring her potential political gain in the primaries before the 2008 US presidential elections. By painting Obama as being the 'Other', his opponents deliberately applied a Manichean method of demonizing their adversary. This is a well-known tactic in populist politics.

When seeking the presidency in 2016, Donald Trump successfully positioned himself within the realm of the Tea Party, and he flirted with many of these anti-Obama conspiracy theories. As will become evident in the following chapter, both the politics and the wider cultural social heritage of the Tea Party indeed played a key role in Donald Trump's election as US President. When tracing the rhetoric on immigration in American politics, from the Neocons to the Tea Party and over to Donald Trump, it becomes evident how nationalist policies travel between different populist movements over time-to emerge as distinctly post-war Neo-Nationalism.

\section{Notes}

1. A Bolivarian Revolution is named after the President of the Second Republic of Venezuela in the early nineteenth century, Simon Bolívar, who throughout Latin America is largely seen as a liberator in the independence fight against European colonialization.

2. BBC News. 2000, 11 February. 'Haider in context: Nazi employment policies'.

3. BBC News. 2001, 27 November. 'Transcript: Bin Laden Video excerpts'.

4. The Independent. 2001, 27 September. 'Storm over Berlusconi "inferior Muslims" remark'.

5. Il Fatto Quotidian. 2013, 23 October. 'Immigrazione, Parlamento Ue chiede la modifica della legge Bossi-Fini'. 
6. The Daily Telegraph. 2010, 2 February. 'Berlusconi says Israel should be an EU member'.

7. Freedom House. 2004, 3 May. 'Global Press Freedom Deteriorates'.

8. Dansk Folkeparti. 2002, October. 'Party programme of the Danish People's Party'.

9. 'Fremskrittspartiets handlingsprogram 2009-2013', 2009.

10. Pew Research Centre. 2010, 18 August. 'Growing Number of Americans Say Obama is a Muslim'.

\section{REFERENCES}

Aistrope, T. (2016). Conspiracy Theory and American Foreign Policy (1st ed.). Manchester: Manchester University Press.

Allen, C. (2010). Islamophobia (1st ed.). London: Routledge.

Ascherson, N. (2002). Neal Ascherson: The Warning Shot. The Observer, London.

Bawer, B. (2007). While Europe Slept: How Radical Islam Is Destroying the West from Within. Norwell: Anchor.

Becker, J. (2019). The Global Machine Behind the Rise of Far-Right Nationalism. The New York Times.

Bergmann, E. (2017). Nordic Nationalism and Right-Wing Populist Politics: Imperial Relationships and National Sentiments. London and New York: Palgrave Macmillan.

Bergmann, E. (2018). Conspiracy \& Populism: The Politics of Misinformation. London: Palgrave Macmillan.

Berlet, C. (Ed.). (1999). Eyes Right!: Challenging the Right Wing Backlash. Boston, MA: South End Press.

Berlusconi Says Israel Should Be an EU Member. (2010). The Daily Telegraph.

Bobba, G., \& Legnante, G. (2016). Italy: A Breeding Ground for Populist Political Communication. In Populist Political Communication in Europe. London: Routledge.

Cedroni, L. (2010). Il linguaggio politico della transizione: tra populismo e anticultura. Armando Editore.

Copsey, N. (2009). Contemporary British Fascism: The British National Party and the Quest for Legitimacy (2nd ed.). Basingstoke: Palgrave Macmillan.

Eggen, D., \& Vandehei, J. (2006). Cheney Cites Justifications For Domestic Eavesdropping. Washington Post.

Fallaci, O. (2006). The Force of Reason (1st ed.). New York, NY: Rizzoli International Publications.

Faye, G. (2001). Why We Fight: Manifesto of the European Resistance. London: Arktos Media Ltd.

Fekete, E. (2018). Europe's Fault Lines: Racism and the Rise of the Right. London: Verso Books. 
Fremskrittspartiets Handlingsprogram 2009-2013. (2009).

Fukuyama, F. (1992). The End of History and the Last Man. New York, NY: Simon and Schuster.

Global Press Freedom Deteriorates. (2004). Freedom House.

Goodwin, M. (2011). New British Fascism: Rise of the British National Party (1st ed.). New York: Routledge.

Griffin, R. (2000). Interregnum or Endgame? The Radical Right in the 'PostFascist' Era. Journal of Political Ideologies, 5(2), 163-178.

Griffin, D. R. (Ed.). (2006). 9/11 and American Empire: Intellectuals Speak Out (Vol. 1). Northampton, MA: Olive Branch Press.

Growing Number of Americans Say Obama Is a Muslim. (2010). Pew Research Center.

Habermas, J. (1998). The Postnational Constellation. Boston: MIT Press.

Hagelund, A. (2003). A Matter of Decency? The Progress Party in Norwegian Immigration Politics. Journal of Ethnic and Migration Studies, 29(1), 47-65.

Haider in Context: Nazi Employment Policies. (2000). BBC News.

Heinisch, R. (2013). Austrian Right-Wing Populism: A Surprising Comeback Under a New Leader. In Exposing the Demagouges. Berlin: Konrad Adenauer Stiftung.

Hellstrom, A. (2016). Trust Us: Reproducing the Nation and the Scandinavian Nationalist Populist Parties. Berghahn Books.

Holan, A. D. (2007). Obama Used a Koran? No, He Didn't. PolitiFact.

Huntington, S. P. (1993). The Clash of Civilizations? Foreign Affairs, 22-49.

Huntington, S. P. (1996). The Clash of Civilizations. London: Simon \& Schuster.

Immigrazione, Parlamento Ue chiede la modifica della legge Bossi-Fini. (2013). Il Fatto Quotidiano.

Iversen, J. M. (1998). Fra Anders Lange Til Carl I. Hagen: 25 Ar Med Fremskrittspartiet. Oslo: Millennium.

Iyer, D. (2001). American Backlash: Terrorists Bring Home War in More Ways than One. South Asian American Leaders of Tomorrow.

Jagers, J. (2006). De Stem van Het Volk! Populisme Als Concept Getest Bij Vlaamse Politieke Partijen. University of Antwerpen.

Judis, J. B. (2018). The Nationalist Revival: Trade, Immigration, and the Revolt Against Globalization. New York, NY: Columbia Global Reports.

Jupskås, A. R. (2013). The Progress Party: A Fairly Integrated Part of the Norwegian Party System. In Exposing the Demagogues: Right-Wing and National Populist Parties in Europe. Berlin: Konrad Adenauer Stiftung.

Jupskås, A. R. (2015a). Institutionalized Right-Wing Populism in Times of Economic Crisis: A Comparative Study of the Norwegian Progress Party and the Danish People's Party. In European Populism in the Shadow of the Great Recession. Colchester: ECPR Press. 
Jupskås, A. R. (2015b). The Persistence of Populism. The Norwegian Progress Party 1973-2009. University of Oslo.

Kessler, G. (2015). Trump's Outrageous Claim that 'Thousands' of New Jersey Muslims Celebrated the 9/11 Attacks. Washington Post.

Kinnvall, C., \& Nesbitt-Larking, P. (2010). The Political Psychology of (de) Securitization: Place-Making Strategies in Denmark, Sweden, and Canada. Environment and Planning D: Society and Space, 28(6), 1051-1070.

Klein, A. (2013). The End of Solidarity? On the Development of Right-Wing Populist Parties in Denmark and Sweden. In Exposing the Demagogues: RightWing and National Populist Parties in Europe. Berlin: Konrad Adenauer Stiftung.

Lane, D. (2005). Berlusconi's Shadow. Eastbourne: Gardners Books.

Levitsky, S., \& Ziblatt, D. (2018). How Democracies Die. New York: Crown.

Lewis, B. (1990). The Roots of Muslim Rage. The Atlantic.

Lucardie, P., \& Voerman, G. (2013). Geert Wilders and the Party for Freedom in the Netherlands: A Political Entrepreneur in the Polder. In Exposing the Demagogues: Right-Wing and National Populist Parties in Europe. Berlin: Konrad Adenauer Stiftung.

Magali, B. (2013). The French National Front from Jean-Marie to Marine Le Pen: Between Change and Continuity. In Exposing the Demagogues: Right-Wing and National Populist Parties in Europe. Berlin: Konrad Adenauer Stiftung.

Merkl, P. H., \& Weinberg, L. (2003). Right-Wing Extremism in the Twenty-First Century. London: Psychology Press.

Mikbakhsh, M., \& Kramar-Schmid, U. (2010). Jörg Haiders Geheime Geldgeschäfte Mit Dem Irakischen Diktator Saddam Hussein. Profil.at.

Mudde, C. (2016). 34 On Extremism and Democracy in Europe. Routledge.

Orsina, G. (2014). Berlusconism and Italy - A Historical Interpretation. Basingstoke: Palgrave Macmillan.

Owen, R. (2008). Profile: The Irrepressible Silvio Berlusconi - Times Online. The Times.

Party Programme of the Danish People's Party. (2002). Retrieved from danskfolkeparti.dk.

Pauwels, T. (2013). Belgium: Decline of National Populism? In Exposing the Demagogues: Right-Wing and National Populist Parties in Europe. Berlin: Konrad Adenauer Stiftung.

Posner, S. (2008). Sarah Posner: For Many on the Religious Right, the Prospect of an Obama Presidency Represents the End of Life as We Know It. The Guardian.

Roemer, J. E., \& Van der Straeten, K. (2004). The Political Economy of Xenophobia and Distribution: The Case of Denmark. Laboratoire d'Econométrie de l'Ecole Polytechnique. Working Paper 2004-03.

Russakof, D., \& Kovaleski, S. (1995). An Ordinary Boy's Extraordinary Rage. 
Rydgren, J. (2007). The Sociology of the Radical Right. Annual Review of Sociology, 33, 241-262.

Schaeffer, F. (2011). Sex, Mom, and God: How the Bible's Strange Take on Sex Led to Crazy Politics-and How I Learned to Love Women (and Jesus) Anyway. ReadHowYouWant.com.

Schwarz, R. (2018). Democracy under Pressure: Polarization and Repression Are Increasing Worldwide. Brussels: Bertelsmann Stiftung.

Scott, P. D. (2013). The War Conspiracy: JFK, 9/11, and the Deep Politics of War (1st ed.). Skyhorse Publishing.

Serrano, R. (1997). Witnesses Say McVeigh Didn't Refer to Nichols. Los Angeles Times.

Shields, J. (2007). The Extreme Right in France: From Pétain to Le Pen. London: Routledge.

Sommer, N., \& Aagaard, S. (2003). Succes: Historien Om Pia Kjarsgaard. Copenhagen: Lindhardt og Ringhof.

Stainforth, T. (2009). The Danish Paradox: Intolerance in the Land of Perpetual Compromise. Review of European and Russian Affairs, 5(1), 83-106.

Storm over Berlusconi 'Inferior Muslims' Remarks. (2001). The Independent.

Terkel, A. (2008). Rep. Steve King: Obama Will Make America A 'Totalitarian Dictatorship'. Think Progress.

Transcript: Bin Laden Video Excerpts. (2001). BBC News.

Trilling, D. (2013). Bloody Nasty People: The Rise of Britain's Far Right (1st ed.). London: Verso.

Widfeldt, A. (2015). Extreme Right Parties in Scandinavia. New York: Routledge. Wodak, R. (2015). The Politics of Fear: What Right-Wing Populist Discourses Mean. New York: Sage.

Woodbridge, S. (2010). Christian Credentials?: The Role of Religion in British National Party Ideology. Journal for the Study of Radicalism, 4(1), 25-54.

Wren, K. (2001). Cultural Racism: Something Rotten in the State of Denmark? Social \& Cultural Geography, 2(2), 141-162.

Ye'or, B. (2005). Eurabia. The Euro-Arab Axis. Cranbury: Fairleigh Dickinson University Press/Associated University Presses. 